\title{
TEMPORAL VARIABILITY OF DROUGHT IN FIELD CROPS IN THE REGION OF KUJAWSKO-POMORSKIE, POLAND
}

\author{
Renata Kuśmierek-Tomaszewska, Stanisław Dudek, Jacek Żarski, Katarzyna Januszewska-Klapa \\ UTP University of Science and Technology in Bydgoszcz, Poland \\ rkusmier@utp.edu.pl
}

\begin{abstract}
The objective of the work, carried out as part of research programme on current change of the regional climate, was to confirm the hypothesis about the increasing frequency and intensity of droughts in May and June in the region of Kujawsko-Pomorskie (central Poland) in the years 1981 - 2010. Furthermore, the aim was to confirm a significant relationship between indicators characterizing meteorological and agricultural droughts. Material for the research was the data from five meteorological measuring points located in the region. Atmospheric precipitation and air temperature in the period of high water needs of cereals and rapeseed (May - June) were used. Statistical methods widespread in climatological studies were applied, particularly the method of trends. The average multiannual totals (1981 - 2010) of rainfall in May - June allow ranking the region of Kujawsko-Pomorskie into the area of the lowest rainfall in Poland. The frequency of meteorological drought in May and June is $23.3-30.0 \%$ in the region. In the analyzed period there were no significant changes in the frequency and intensity of these droughts with the passage of years. Rainfall shortages in cereal crops and rapeseed production range on average from -19 to $-35 \mathrm{~mm}$, and extend to maximum of -93 to $-117 \mathrm{~mm}$. The values of shortages did not show any significant changes in the years of the study. The significant dependence between the indicators of meteorological and agricultural droughts allows for determination of the rainfall shortages in crop production on the basis of the SPI values.
\end{abstract}

Key words: meteorological and agricultural drought, cereal, rapeseed, atmospheric rainfall shortage.

\section{Introduction}

The region of Kujawsko-Pomorskie, which is located in the northern part of central Poland, is mainly the area of agricultural production. Agricultural land in this region covers over 1 million ha, of which cereal crops and rapeseed are grown on 700.000 hectares (Statistics Poland, 2018). Production of these crops is associated with climatic risk resulting from the frequent occurrence of droughts during the period of high water needs, spanning May and June (Labędzki, 2007; Doroszewski et al., 2012; Łabędzki \& Bąk, 2014; Żarski et al., 2017).

The main feature of droughts is their irregularity, resulting from a high variation of atmospheric precipitation in time. This variation, which consists of the occurrence of radically different weather conditions in the same calendar periods of particular years, is the most important feature characterizing the climate of central Poland, referred to as temperate and transitional between oceanic and continental climates. According to the forecasts of climate change, the main symptom of which is the increase in the air temperature, in the temperate latitudes the frequency of extreme weather conditions and thus the occurrence of droughts are to increase (Kundzewicz \& Kozyra, 2011; IPCC, 2014). Under the projections and simulations of climate change for the years 20502060, the determined probabilities for occurrence of extremely dry periods in central Poland indicate on average their two-, three- and fourfold increase depending on the scenario of climate change (Kuchar et al., 2015). Many research results indicate that these changes are already taking place. Somorowska (2009) stated that during the last two decades of the 20th century, dry months occurred in the most of analyzed regions in Poland. Jania \& Zwoliński (2011), Wibig (2012), Skowera (2014), and Ziernicka-Wojtaszek (2015) have come to similar conclusions.

The basic objective of the work, carried out as part of research programme on current changes in the regional climate, was to confirm or deny the hypothesis about the increasing frequency and intensity of droughts in May and June in the region of KujawskoPomorskie in the years $1981-2010$. The work was also aimed at confirming a significant relationship between indicators characterizing meteorological and agricultural droughts.

\section{Materials and Methods}

Material for the research was meteorological data of standard measurements of atmospheric precipitation and air temperature in the period of high water needs of cereals and rape, spanning May and June. The meteorological data were derived from three local branches of the Central Research Center for Cultivar Testing located in Chrząstowo, Głębokie and Głodowo. Also data of meteorological measurements carried out at the Research Station of UTP University of Science and Technology in Bydgoszcz, located in Mochełek rural area, were used. In order to check the homogeneity of rainfall data from the four measuring points, they were compared to the sole reference station in the region, operating in the national network of the Institute of Meteorology and Water Management (IMGW-PIB), located in Torun. All measuring points are located in the region of Kujawsko-Pomorskie. Chrząstowo and Mochełek are located in the northern part of the region in the Pojezierze Krajeńskie, and 


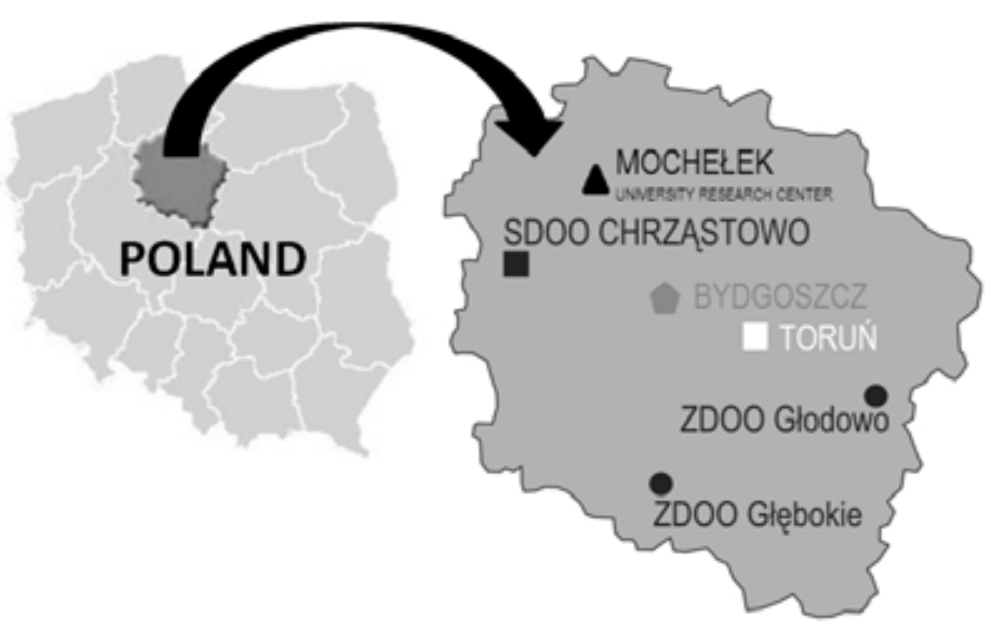

Figure 1. Location of the meteorological measuring points.

Table 1

Drought classes according to the standardized precipitation index SPI (Labędzki \& Bąk, 2013)

\begin{tabular}{|l|l|l|}
\hline \multicolumn{1}{|c|}{ Type of period } & \multicolumn{1}{|c|}{ SPI } & Graphic designation \\
\hline Extremely dry & $\leq-2.00$ & \\
\hline Very dry & $-1.99 \div-1.50$ & \\
\hline Moderate dry & $-1.49 \div-1.00$ & \\
\hline Slightly dry & $-0.99 \div-0.50$ & \\
\hline
\end{tabular}

the other two are located in the southern part of the province: Głębokie in Pojezierze Gnieźnieńskie (Równina Inowrocławska) and Głodów in Pojezierze Dobrzyńskie (Wysoczyzna Płońska) (Figure 1). The geographical location of the listed sites is presented in the Results section (Table 2). They all are located in poorly urbanized and industrialized areas, which decreases the impact of urban anthropogenic factors to a minimum. To ensure the homogeneity of the meteorological data series, following the recommendations of the World Meteorological Organisation (WMO), only the totals of rainfall in the 30-year normal period were statistically analysed (1981-2010). Next to the representativeness of the data, it is also important, whether rules of comparability of meteorological measurements and observations provided by WMO are respected. Failure to comply with those rules often leads to erroneous conclusions due to the lack of comparability of measurement sites, measuring instruments, or data averaging procedures (Kuśmierek-Tomaszewska, Żarski, \& Dudek, 2012).

Droughts were identified on the basis of the standardized precipitation index (SPI) (Bąk \& Łabędzki, 2002). The SPI was calculated separately for each location; 30-year data series of twomonth precipitation totals were normalized by the transforming function $f(P)=(P)^{1 / 3}$. Based on the calculated values of the SPI, the drought level was determined (Table 1) according to the scale stand in rainfall monitoring in Poland, run by the Institute of Technology and Life Sciences (Labędzki \& Bąk, 2013).

The indicator SPI is used to identify meteorological drought only on the basis of rainfall data. To determine the agricultural drought (RS), an index of deficiency of real rainfall (Pr) was compared to the optimum rainfall totals $(\mathrm{Po})$ elaborated by Klatt for plants grown on soil of medium compactness (Schwarz, 1970). For cereal crops and rapeseed, the optimum rainfall is $65 \mathrm{~mm}$ in May at the average air temperature of 13 ${ }^{\circ} \mathrm{C}$, and $70 \mathrm{~mm}$ in June at the average temperature of $16{ }^{\circ} \mathrm{C}$. The temperature difference in relation to the stated increases or decreases the optimum rainfall of 5 $\mathrm{mm}$ for every $1{ }^{\circ} \mathrm{C}$ of the difference (Schwarz, 1970).

The following statistical methods commonly used in climatological studies were applied (Garnier, 1996): analysis of regression and correlation, and analysis of trends that employ linear regression equations in relation to the 30 -year measurement period.

\section{Results and Discussion}

Multiannual averages (1981-2010) of atmospheric precipitation in the period of high water needs of cereals and rapeseed (from May to June) calculated 
Table 2

The average multiannual $(1981$ - 2010) total of rainfall in the period of May - June in the region of Kujawsko-Pomorskie and statistics defining their temporal variability

\begin{tabular}{|l|c|c|c|c|c|c|}
\hline \multicolumn{1}{|c|}{ Location } & Latitude & Longitude & $\begin{array}{c}\text { Avg. rainfall } \\
(\mathrm{mm})\end{array}$ & $\begin{array}{c}\text { Max. rainfall } \\
(\mathrm{mm})(\text { year })\end{array}$ & $\begin{array}{c}\text { Min. rainfall } \\
(\mathrm{mm})(\text { year })\end{array}$ & $\begin{array}{c}\text { CV } \\
(\%)\end{array}$ \\
\hline Mochle & $53^{\circ} 13^{\prime} \mathrm{N}$ & $17^{\circ} 51^{\prime} \mathrm{E}$ & 102.1 & $178.6(2007)$ & $27.0(2008)$ & 39.3 \\
\hline Chrząstowo & $53^{\circ} 11^{\prime} \mathrm{N}$ & $17^{\circ} 35^{\prime} \mathrm{E}$ & 110.4 & $195.2(2007)$ & $32.8(1989)$ & 40.0 \\
\hline Toruń & $53^{\circ} 03^{\prime} \mathrm{N}$ & $18^{\circ} 36^{\prime} \mathrm{E}$ & 108.6 & $182.0(2010)$ & $35.0(1989)$ & 34.7 \\
\hline Głodowo & $52^{\circ} 50^{\prime} \mathrm{N}$ & $19^{\circ} 15^{\prime} \mathrm{E}$ & 119.7 & $208.7(2009)$ & $54.3(2000)$ & 32.3 \\
\hline Głębokie & $52^{\circ} 39^{\prime} \mathrm{N}$ & $18^{\circ} 27^{\prime} \mathrm{E}$ & 111.2 & $187.9(1985)$ & $48.5(1989)$ & 33.9 \\
\hline
\end{tabular}

for particular locations proved very strong consistency and compliance with reference data obtained from the station of The Institute of Meteorology and Water Management - National Research Institute (IMGWPIB) in Toruń (Table 2). The lowest rainfall totals were in Mochle, and the highest in Głodowo - set in Wyżyna Płońska (100 m a. s. 1.). These results are consistent with the existing studies carried out in the national (Czarnecka \& Nidzgorska-Lencewicz, 2012) or regional scale (Żarski et al., 2014). The long-term rainfall in the period of May-June for the analyzed locations, on average amounted to $110.4 \mathrm{~mm}$ (Table 2), which makes the region of Kujawsko-Pomorskie the area with the lowest atmospheric precipitation in Poland (compared to Lorenc, 2005).

Far greater than the spatial variation of rainfall in the analyzed period was their variation in time, which is distinctive of the climate of Central Poland. This is evidenced by both extreme values of totals and high coefficients of variability $(\mathrm{CV})$, amounting to $32.3-40.0 \%$, depending on the locality. The difference between the maximum and minimum rainfall in May and June in the years 1981 - 2010 was on average around $150 \mathrm{~mm}$, so it exceeded the optimum rainfall for plants in the stages of their high water needs.

A high temporal variability but less spatial variability were also related to the frequency of occurrence of meteorological drought in the period of high water needs of cereals and rapeseed (Table 3). In the analyzed multiannual period, 7 to 9 meteorological droughts occurred in particular locations of the Kujawsko-Pomorskie region, which means a frequency of 23.3 to $30.0 \%$. This result is fully consistent with the study of Łąbędzki (2007), made for central Poland. Noteworthy is the high consistency of drought occurrences in the analyzed locations. The entire region experienced drought in the years 1983, 2000 and 2008. In four of the analyzed locations, drought occurred in 1989, 1992 and 2006, and in three locations in 2003. The adverse effect of the evidence of drought is the reduction in yields and deterioration of their quality (Doroszewski et al., 2012; Żarski et al.,
2013; Łabędzki \& Bąk, 2017). According to the study by Żarski et al. (2017), regional losses in yields and harvests of barley, due to the occurrence of drought in May and June, are on average $14 \%$, and the maximum of $23 \%$. Minimizing the effects of agricultural droughts is associated with the development of plant irrigation. According to many studies on agricultural and horticultural plants, irrigation contributes to the regular rhythm of plant growth and development as well as the intensification of physiological processes. As a result, it increases yields and stabilizes them in subsequent years, and also positively affects the yield quality (Żarski et al., 2013). According to Żarski et al. (2017), the application of irrigation in dry periods not only prevents yield decreases, but also ensures a higher level of yield, compared to the average one achieved without using this treatment.

In the years $1981-2010$, there was no evidence of increasing frequency and intensity of meteorological drought in the period covering May and June in the selected locations of the Kujawsko-Pomorskie region (Figure 2). Nosignificant changes were observed in the SPI values over the period of time. The coefficients of determination characterizing these relationships were low, so it is difficult to point to a trend of changes over time. However, a great temporal variability of the SPI values was found, which is typical for the climate of central Poland.

A similar absence of significant trends and tendencies was also seen regarding the agricultural drought indicators expressed as the difference of the real and optimum rainfall, calculated for cereal plants and rapeseed, grown on soils of medium compactness (Figure 3). This deficit, as well as SPI values, were characterized by a very high time variability. They were on average from - 19 to $-35 \mathrm{~mm}$ depending on the location, which means that the production of cereals and rapeseed in the region of Kujawsko-Pomorskie is limited by the shortage of rainwater. The maximum rainfall deficit ranged from $-93.2 \mathrm{~mm}$ in Głodowo and $-22.3 \mathrm{~mm}$ in Głębokie (2000) to $-111.6 \mathrm{~mm}$ in Chrząstowo and $-117.0 \mathrm{~mm}$ in Mochle (2008). In 
The occurrence of meteorological droughts in the period of high water needs of cereal crops and rapeseed (May - June) in the years 1981 - 2010 in the region of Kujawsko-Pomorskie

\begin{tabular}{|c|c|c|c|c|c|}
\hline Year & Mochle & Chrząstowo & Toruń & Głodowo & Głębokie \\
\hline \multicolumn{6}{|l|}{1981} \\
\hline \multicolumn{6}{|l|}{1982} \\
\hline \multicolumn{6}{|l|}{1983} \\
\hline \multicolumn{6}{|l|}{1984} \\
\hline \multicolumn{6}{|l|}{1985} \\
\hline \multicolumn{6}{|l|}{1986} \\
\hline \multicolumn{6}{|l|}{1987} \\
\hline \multicolumn{6}{|l|}{1988} \\
\hline \multicolumn{6}{|l|}{1989} \\
\hline \multicolumn{6}{|l|}{1990} \\
\hline \multicolumn{6}{|l|}{1991} \\
\hline \multicolumn{6}{|l|}{1992} \\
\hline \multicolumn{6}{|l|}{1993} \\
\hline \multicolumn{6}{|l|}{1994} \\
\hline \multicolumn{6}{|l|}{1995} \\
\hline \multicolumn{6}{|l|}{1996} \\
\hline \multicolumn{6}{|l|}{1997} \\
\hline \multicolumn{6}{|l|}{1998} \\
\hline \multicolumn{6}{|l|}{1999} \\
\hline \multicolumn{6}{|l|}{2000} \\
\hline \multicolumn{6}{|l|}{2001} \\
\hline \multicolumn{6}{|l|}{2002} \\
\hline \multicolumn{6}{|l|}{2003} \\
\hline \multicolumn{6}{|l|}{2004} \\
\hline \multicolumn{6}{|l|}{2005} \\
\hline \multicolumn{6}{|l|}{2006} \\
\hline \multicolumn{6}{|l|}{2007} \\
\hline \multicolumn{6}{|l|}{2008} \\
\hline \multicolumn{6}{|l|}{2009} \\
\hline 2010 & & & & & \\
\hline & 1 & 2 & 1 & 1 & 0 \\
\hline & 1 & 1 & 2 & 2 & 5 \\
\hline & 4 & 1 & 1 & 2 & 1 \\
\hline & 3 & 5 & 4 & 4 & 1 \\
\hline
\end{tabular}

White cells indicate periods without drought

the case of such high deficit, substantial losses in the regional crop production occur.

There are many indicators for quantitative assessment and drought monitoring, but despite identifying and expressing the intensity of the phenomenon in different units, they indicate a great compliance of the course from statistical point of
Table 3

\section{and}


Mochle

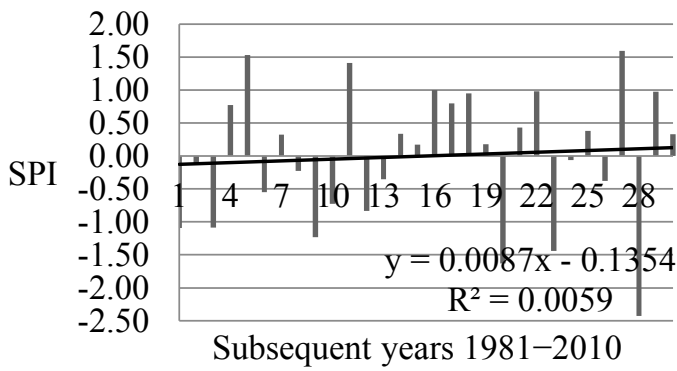

Głodowo

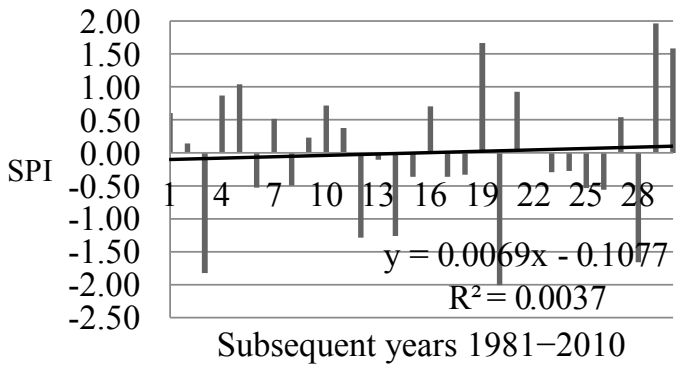

Chrząstowo

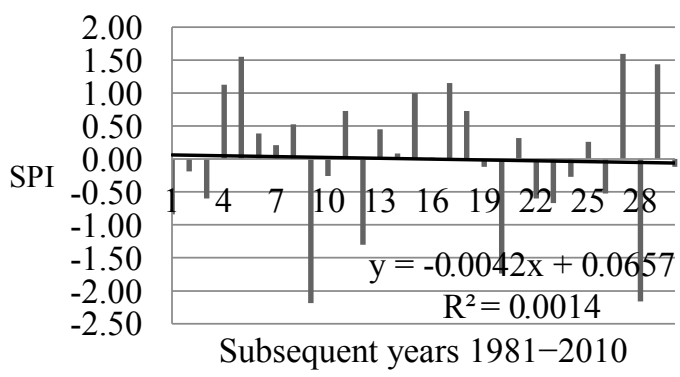

Głębokie

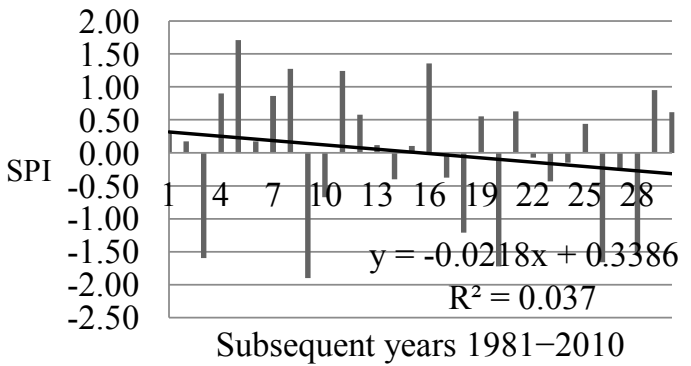

Figure 2. Temporal variation of the meteorological drought index (SPI) in the period of high water needs of cereals and rapeseed (May - June) in the locations of Kujawsko-Pomorskie in the years $1981-2010$.

Mochle

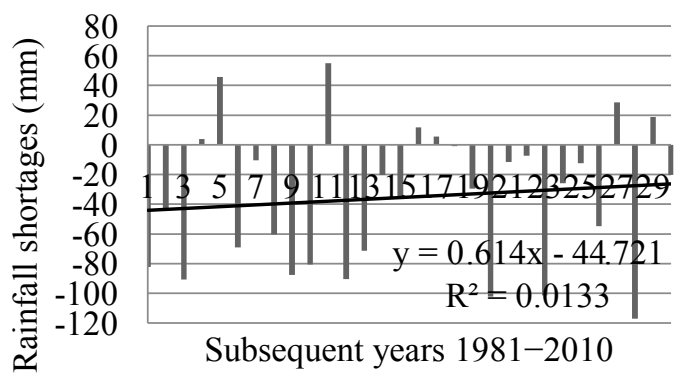

Głodowo

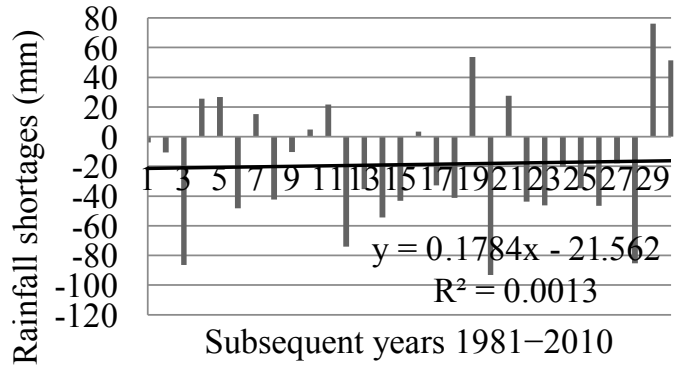

Chrząstowo

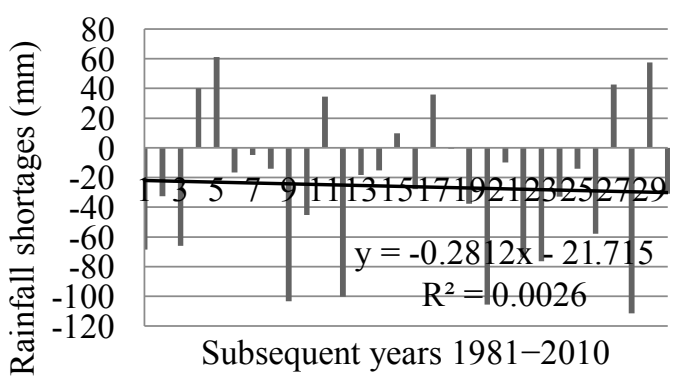

Głębokie

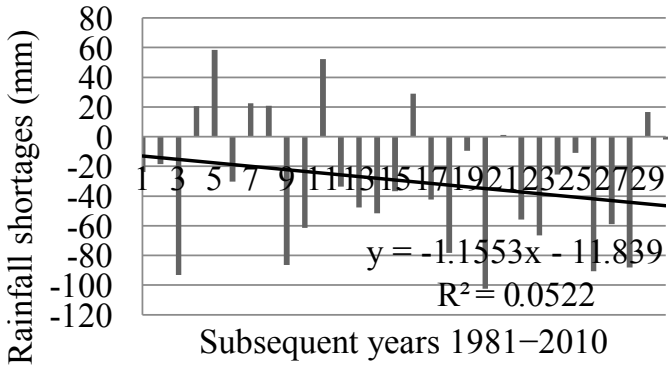

Figure 3. Temporal variation of the agricultural drought index (RS) in the period of high water needs of cereals and rapeseed (May - June) in the locations of Kujawsko-Pomorskie in the years $1981-2010$. 


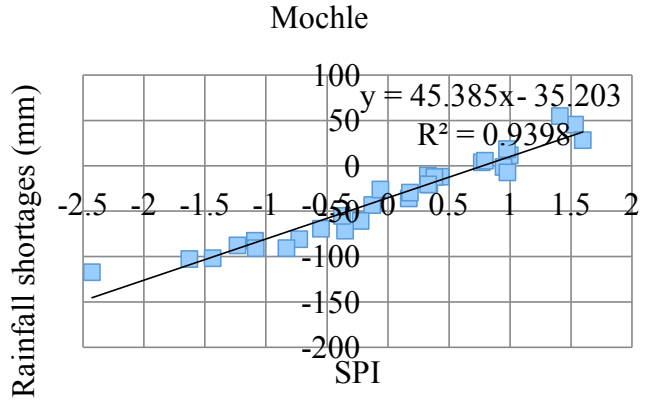

Głodowo

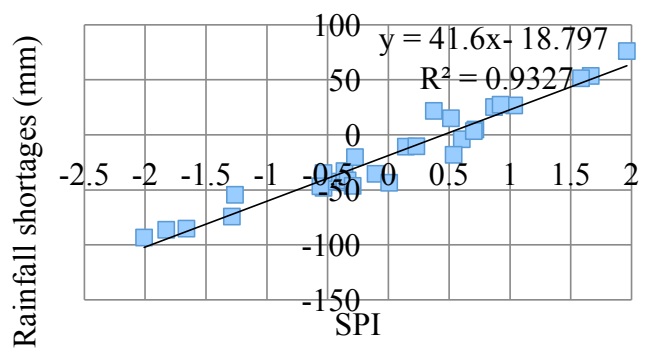

Chrząstowo

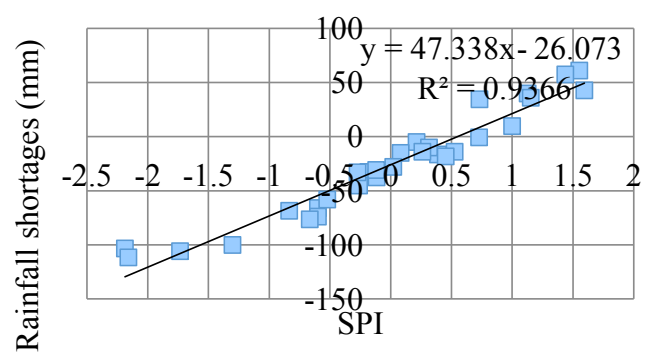

Głębokie

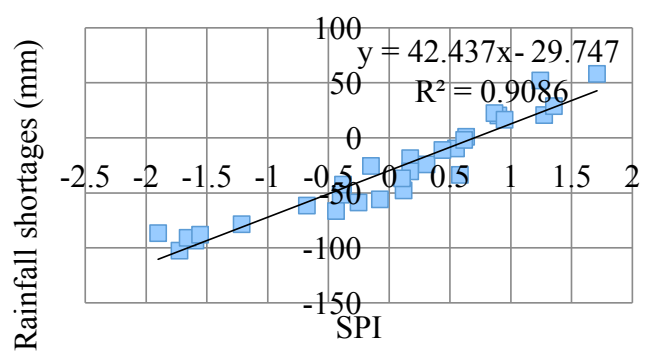

Figure 4. Relationship between the meteorological and agricultural drought indices in the period of high water needs of cereals and rapeseed (May - June) in the locations of Kujawsko-Pomorskie in the years 1981 - 2010.

rainfall shortages during the growing season based on SPI, so only on the basis of rainfall data. These shortages of rainfall determine the irrigation needs of the tested plants in the analyzed region, as well.

\section{Conclusions}

1. The average multiannual $(1981$ - 2010) totals of atmospheric precipitation in May - June, in particular locations allow ranking the region of Kujawsko-Pomorskie into the area of the lowest rainfall in Poland.

2. The frequency of meteorological drought in May and June is $23.3-30.0 \%$ in the region of KujawskoPomorskie. In the analyzed period, there were no significant changes in the frequency and intensity of these droughts with the passage of years. The hypothesis about the increasing frequency and intensity of droughts in May and June in the region of Kujawsko-Pomorskie (central Poland) was not confirmed.

3. The production of cereals and rapeseed in the region of Kujawsko-Pomorskie is carried out under the conditions of atmospheric rainfall shortages, which on average range from -19 to -35 $\mathrm{mm}$, and extend to maximum of -93 to $-117 \mathrm{~mm}$, depending on the locality. The values of shortages did not show any significant changes in the years of the study of $1981-2010$.

4. The significant interdependence between the indicators of meteorological and agricultural droughts allows for determination of the rainfall shortages in plant production on the basis of the SPI values.

\section{References}

1. Bąk, B., \& Łabędzki, L. (2002). Assessing drought severity with the relative precipitation index (RPI) and the standardized precipitation index (SPI). Journal of Water Land Development, 6, 89-105.

2. Czarnecka M., \& Nidzgorska-Lencewicz, M. (2012). Wieloletnia zmienność sezonowych opadów w Polsce. (Multiannual variability of seasonal precipitation in Poland). Woda-Środowisko-Obszary Wiejskie, 12.2(38), 45-60. (in Polish).

3. Garnier, B.J. (1996). Podstawy klimatologii. (Fundamentals of climatology). Warszawa: IMGW Press (in Polish).

4. Doroszewski, A., Jadczyszyn, J., Kozyra, J., Pudełko, R., Stuczyński, T., Mizak, K., Łopatka, A., Koza, P. Górski, T., \& Wróblewska, E. (2012). Podstawy systemu monitoringu suszy rolniczej. (Fundamentals of the agricultural drought monitoring system). Woda-Środowisko-Obszary Wiejskie, 12 2(38), 77-91. (in Polish).

5. IPCC Report. (2014). Climate Change 2014 - Synthesis Report 2014. Contribution of Working Groups I, II and III to the Fifth Assessment Report of the Intergovernmental Panel on Climate Change [Core Writing 
Team, R.K. Pachauri and L.A. Meyer (Eds.)]. IPCC, Geneva, Switzerland, Retrieved February 23, 2018, from: https://www.ipcc.ch/pdf/assessment-report/ar5/syr/SYR_AR5_FINAL_full_wcover.pdf.

6. Jania, J., \&Zwoliński,Z.(2011). Ekstremalne zdarzenia meteorologiczne, hydrologiczne igeomorfologiczne w Polsce. (Extreme meteorological, hydrological and geomorphological events in Poland). Landform Analysis, 15, 51-64. (in Polish).

7. Kuchar, L., Iwański, S., Gąsiorek, E., \& Diakowska, E. (2015). Simulation of hydrothermal conditions for crop production purpose until 2050-2060 and selected climate change scenarios for north central Poland. Infrastructure and Ecology of Rural Areas, 2(1), 319-334 DOI: 10.14597/infraeco.2015.2.1.026 (in Polish).

8. Kundzewicz, Z., \& Kozyra, J. (2011). Ograniczanie wpływu zagrożeń klimatycznych w odniesieniu do rolnictwa i obszarów wiejskich. (Reducing impacts of climatic threats to agriculture and rural areas). Polish Journal of Agronomy, 7, 68-81. (in Polish).

9. Kuśmierek-Tomaszewska, R., Żarski, J., \& Dudek, S. (2012). Meteorological automated weather station data application for plant water requirements estimation. Computers and Electronics in Agriculture, 88, 44-51. DOI: 10.1016/j.compag.2012.07.002.

10. Lorenc, H. (2005). Atlas klimatu Polski. (Atlas of climate in Poland). Warszawa: IMGW Press. (in Polish).

11. Łabędzki, L. (2007). Estimation of local drought frequency in central Poland using the standardized precipitation index SPI. Irrigation and Drainage, 56, 67-77. DOI: 10.1002/ird.285.

12. Łabędzki, L., \& Bąk, B. (2013). Monitoring i prognozowanie przebiegu i skutków deficytu wody na obszarach wiejskich. (Monitoring and forecasting the course and impact of water deficit in rural areas). Infrastructure and Ecology of Rural Areas, 2(1), 65-76. (in Polish).

13. Łabędzki, L., \& Bąk, B. (2014). Meteorological and agricultural drought indices used in drought monitoring in Poland: a review. Meteorology, Hydrology and Water Management, 2(2), 3-14.

14. Łabędzki, L., \& Bąk, B. (2017). Impact of meteorological drought on crop water deficit and crop yield reduction in Polish agriculture. Journal of Water and Land Development, 34, 181-190. DOI: 10.1515/ jwld-2017-0052.

15. Schwarz, K. (1970). Technik und Technologie der Beregnung. (Engineering and technology of irrigation). Berlin: VEB Deutscher Landwirtschaftsverlag. (in German).

16. Somorowska, U. (2009). Wzrost zagrożenia suszą hydrologiczną w różnych regionach geograficznych Polski w XX wieku. (Increase in the hydrological drought risk in different geographical regions of Poland in the 20th century). Prace $i$ Studia Geograficzne, 43, 97-114. (in Polish).

17. Skowera, B. (2014). Zmiany warunków hydrotermicznych na obszarze Polski (1971-2010). (Changes of hydrothermal conditions in the Polish area (1971-2010)). Fragmenta Agronomica, 31(2), 74-87. (in Polish).

18. Statistics Poland (2018). Statistical Yearbook of Agriculture. Retrieved February 23, 2018, from: http:// stat.gov.pl.

19. Tokarczyk, T., \& Szalińska, W. (2013). The operational drought hazard assessment scheme-performance and preliminary results. Archives of Environmental Protection, 39(3), 61-77. DOI: 10.2478/aep-20130028 .

20. Wibig, J. (2012). Warunki wilgotnościowe w Polsce w świetle wskaźnika standaryzowanego klimatycznego bilansu wodnego. (Moisture conditions in Poland in view of the SPEI index). Woda-Środowisko-Obszary Wiejskie, 12, 2(38), 329-340. (in Polish).

21. Ziernicka-Wojtaszek, A. (2015). Klimatyczny bilans wodny na obszarze Polski w świetle współczesnych zmian klimatu. (Climatic water balance in Poland in the light of the present day climate change). WodaŚrodowisko-Obszary Wiejskie, 15, 4(52), 93-100. (in Polish).

22. Żarski, J., Dudek, S., Kuśmierek-Tomaszewska, R., Rolbiecki, R., \& Rolbiecki, S. (2013). Prognozowanie efektów nawadniania roślin na podstawie wybranych wskaźników suszy meteorologicznej i rolniczej. (Forecasting effects of plants irrigation based on selected meteorological and agricultural drought indices). Annual Set of The Environment Protection, 15, 2185-2203. (in Polish).

23. Żarski, J., Dudek, S., Kuśmierek-Tomaszewska, R., Bojar, W., Knopik, L., \& Żarski, W. (2014). Agroklimatologiczna ocena opadów atmosferycznych okresu wegetacyjnego w rejonie Bydgoszczy. (Agro-climatological assessment of the growing season rainfall in the Bydgoszcz region). Infrastructure and Ecology of Rural Areas, II(3), 643-656. (in Polish).

24. Żarski, J., Dudek, S., Kuśmierek-Tomaszewska, R., \& Żarski, W. (2017). Effects of agricultural droughts in the province of Kujawsko-Pomorskie and possibilities of minimizing their impact. Infrastructure and Ecology of Rural Areas, II(2), 813-824. DOI: /10.14597/infraeco.2017.2.2.063. 